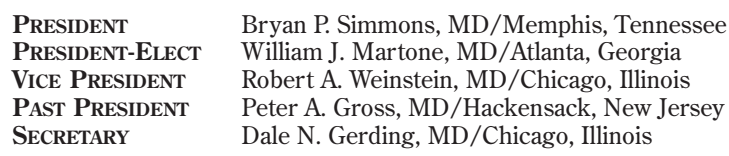

Bryan P. Simmons, MD/Memphis, Tennessee

William J. Martone, MD/Atlanta, Georgia

Robert A. Weinstein, MD/Chicago, Illinois

Peter A. Gross, MD/Hackensack, New Jersey

Dale N. Gerding, MD/Chicago, Illinois

\author{
Treasurer Elias Abrutyn, MD/Philadelphia, Pennsylvania \\ CounciLor Edward S. Wong, MD/Richmond, Virginia \\ CouncIlor Leigh G. Donowitz, MD/Charlottesville, Virginia \\ CouncILOR Timothy W. Lane, MD/Greensboro, North Carolina \\ CouncILoR John W. Froggatt, III, MD/Asheville, North Carolina
}

\title{
Fall Training Course in Hospital Epidemiology
}

The Fall SHEA/CDC/AHA Training Course in Hospital Epidemiology will be held in Miami, Florida, at the Hotel Inter-Continental, October 14-17, 1995. The program is designed for hospital epidemiologists, but would be of interest to infection control practitioners or those who are looking for a course that will provide them with the most current information concerning infection control practices and epidemiological methods in health care. The course is conducted by an outstanding faculty comprised of nationally recognized experts in the field of healthcare epidemiology.

Persons interested in attending this course should apply early, as the course frequently is oversubscribed. Applicants who apply late may have to be turned away. Participation in the course is limited to ensure the quality of training.

Of special note is that up to 23 credit hours of CME in Category 1 of the American Medical Association's
Physician's Recognition Award may be obtained by attending the training course, and the American Association of Critical-Care Nurses has approved the training course for 24.5 contact hours.

For more information or registration materials, write to SHEA Meetings Dept, 875 Kings Hwy, Suite 200, Woodbury, NJ 08096-3172; telephone (609) 845-1720, fax (609) 853-0411.

\section{Current Events: Opportunities for Epidemiologists}

During the month of July, news reports described the heat wave that contributed to more than 500 deaths in Chicago, and news commentators compared it to man-made disasters such as jumbo jet crashes. Early in August, the New York Times reported that Russian life expectancy continued to plunge and also described an inquiry concerning anesthesiarelated deaths at a New York hospital.

Each of these stories presented a wealth of investigative, as well as educational, opportunities to the epidemiologist trained in infectious diseases epidemiology and in the evaluation of common cause or special cause variation. Where is the epidemic curve for deaths in Chicago for the month of July? How many preventable years of life were lost? What was the operational definition of "heat related"? Are the changes in the Russian life expectancy real, related to discrete causes, or are they related to the methodologies of data collection? Are the particular hospital's anesthesia mishaps evidence of inferior quality, or were they unrelated events? What is the pattern of these events over time, and how does the hospital mentioned in the newspaper compare to those that are not in the newspaper?

As these examples illustrate, even after we have developed and implemented methodologies for the control of tuberculosis, bloodborne pathogens, and other emerging resistant pathogens, and addressed the optimal methods for surveillance and reporting of indicator nosocomial infections, there will be a huge array of noninfectious epidemiological problems that can be addressed by methodologies similar to those that we traditionally have applied to infection control-related issues.

Brief items of interest for SHEA News or the Newsletter may be sent to $C$. Glen Mayhall, MD, SHEA, Newsletter Editor, Division of Infectious Diseases, Route 0835, The Former Shriner's Bldg, Room 2-64B; University of Texas Medical Branch; Galveston, TX 77555-0835. 